\title{
Liberal versus neo-developmental convention to growth: Why has Brazil shown a poor performance since the 1980s?
}

\author{
ANDRÉ NASSIF \\ CARMEM FEIJÓ*
}

The main goal of our paper is to provide analytical arguments to explain why Brazil has not been able to restore its long-term capacity for economic growth, especially compared with its economy in the 1950-1979 period (7.3 per cent per year on average) or even with a select number of emerging economies in the 1980-2010 period (6.7 per cent per year on average, against 2.3 per cent per year on average in Brazil in the same period). We build our idea of convention to growth based on the Keynesian concept of convention. For our purposes, this concept could be briefly summarized as the way in which the set of public and private economic decisions related to different objectives, such as how much to produce and invest, how much to charge for products and services, how to finance public and private debt, how to finance research and development, and so on, are indefinitely — or at least until there is no change - carried out by the political, economic and social institutions. This analytical reference can be connected to the Neo-Schumpeterian National Innovation System (NIS) concept, which emphasizes not only institutions associated with science and technology per se, but also the complex interaction among them and other institutions. In this paper we identify two conventions to long-term growth in the last three decades in Brazil: the liberal and the neo-developmental. We show that the poor performance in the Brazilian economy in terms of real GDP growth from the 1980 s on can be explained by a weak coordination between short-term macroeconomic policies and long-term industrial and technological policies. This weak coordination, in turn, can be associated with the prevalence of the liberal convention from the 1990s on, which has emphasized price stabilization to the detriment of a neo-developmental strategy whose primary goal is to sustain higher rates of growth and full employment in Brazil.

Keywords: convention; National Innovation System; macroeconomic policy; Brazil.

JEL Classification: 01; 02; 05.

\footnotetext{
"Respectively, Professor of Economics at Fluminense Federal University (UFF) and economist at the Brazilian Development Bank (BNDES). E-mail: andrenassif27@gmail.com; Professor of Economics at Fluminense Federal University (UFF). E-mail: .cfeijo@terra.com.br.
} 


\section{INTRODUCTION}

The main goal of our paper is to provide analytical arguments to explain why Brazil has not been able to restore its long-term capacity for economic growth, especially compared with its economy in the $1950-1979$ period $(7.3$ per cent per year on average) or even with a select number of emerging economies (Russia, India, China and South Africa) in the 1980-2010 period (6.7 per cent per year on average, against 2.3 per cent per year on average in Brazil in the same period). Figure 1 shows that the real GDP growth in Brazil in the 1980-2010 period was not only lower than the other BRICS countries (Russia, India, China and South Africa), but also lower than the world economy.

Figure 1: Real GDP percentage growth at Purchasing Power Parity (PPP) in US\$ of 2005:

Brazil, selected developing \& emerging countries and the world economy 1980-2010

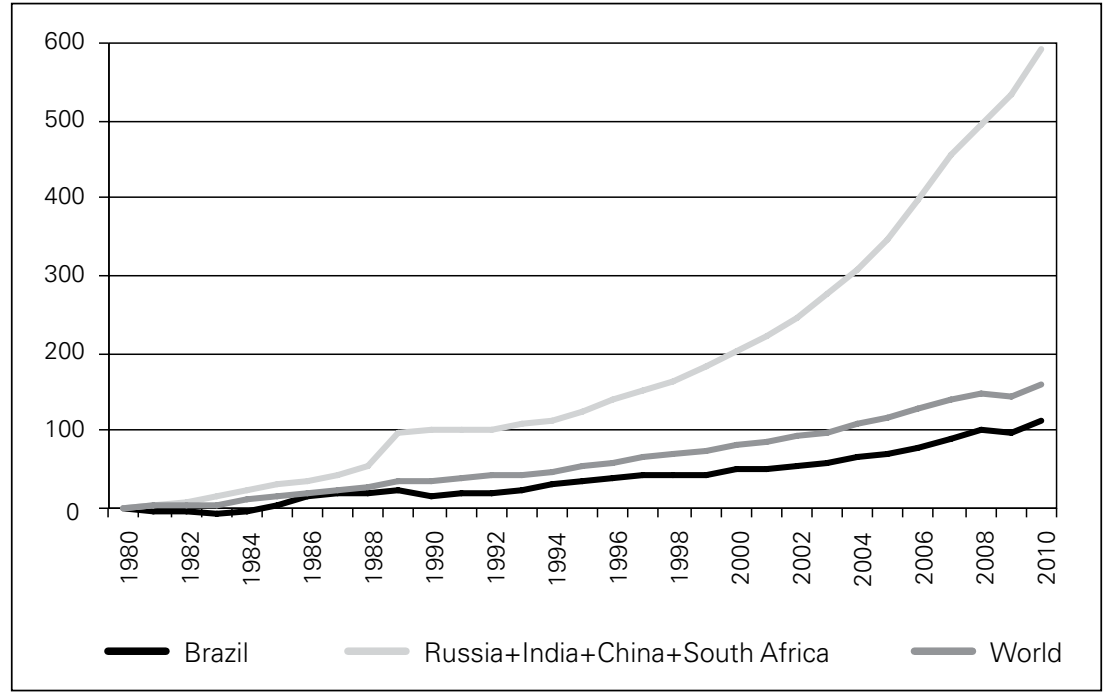

Source: Ipeadata, from WDI.

The main analytical reference we will use is the Keynesian concept of convention (Keynes, 1936, ch. 12). In Keynes' vision, conventions are important to support uncertain decisions. Rules and habits, which are characteristics of an economic environment of monetary economies, ${ }^{1}$ are the necessary institutional apparatus to induce economic agents to make sensible choices. To put it in other words without conventions (or weak conventions), long-term decisions, the ones responsible for long-term growth, would be impaired. Thus, the evaluation of the dynamics of a monetary economy, working on the hypothesis of non-probabilistic uncertainty,

\footnotetext{
${ }^{1}$ For a definition of Keynes' concept of monetary economy see Davidson (1978), Carvalho (1992), among others.
} 
presupposes the understanding of how the political economy deals with the inherent uncertainty, how institutions created to deal with uncertainty are coordinated, and how a convention of development is perceived by the economic agents. For our purposes, this concept could be briefly summarized as the way in which the set of public and private economic decisions related to different objectives, such as how much to produce and invest, how much to charge for products and services, how to finance public and private debt, how to finance research and development, and so on, are indefinitely — or at least until there is no change - carried out by the political, economic and social institutions.

This analytical reference can be connected to the Neo-Schumpeterian National Innovation System (NIS) concept, which emphasizes not only institutions associated with science and technology per se, but also the complex interaction among them and other institutions. We will assume that industrial policy, at different moments in time, will be taken as an indication of the convention of the NIS. Accordingly, our main hypothesis is that a pro-growth convention is a necessary condition to sustain economic development in the long run, while the sufficient condition is that the former results from a strong coordination between the set of political, economic and social institutions that are responsible directly or indirectly for sustained growth, price stability, reasonable income distribution, external balance, technical progress, research and development, and so forth.

In addition to this Introduction, the paper is organized as follows. Second section proposes an analytical approach to convention to growth based on both the Keynes view of convention and the Neo-Schumpeterian view of the NIS. The third section develops the analysis of the connection between macroeconomic short-term policy orientation and industrial policy in Brazil since the 1990s, and this is broken down into four Subsections. Subsection (1) briefly summarizes the convention to growth in the 1970s and how the strategy of growth, with the external debt-cuminflation, led the economy to the severe crisis in the 1980s. Subsection (2) shows how in the Fernando Collor de Mello, Itamar Franco and Fernando Henrique Cardoso governments (1990-2002), industrial and technological policies were, in practice, neglected, in favour of stabilization policies. In other words, the convention to growth changed sharply compared with the previous period. Subsection (3) asserts that, although in the two mandates of the Luiz Inacio Lula da Silva government there was an enormous effort to restore a more ambitious and complex industrial and technological policy - especially in the second mandate, a strong coordination of this policy with the main instruments of macroeconomic policy was missed. Subsection (4) shows that in the Dilma Rousseff government (2011-2014) there has been an attempt at improving the coordination among macroeconomic and industrial and technological policies. However, as of early-2013, growth had not yet resumed. Our main hypothesis is that the still poor performance of the Brazilian economy could be explained not only by the weak neo-developmental convention to growth, but also by the lack of coordination of the NIS stricto sensu with the conventional short-term macroeconomic policies (monetary, fiscal and exchange rate policies). In this context, if we recognize that the Rousseff govern- 
ment has introduced a set of supply side incentives (e.g., tax exemptions to consume and investments), then the instruments of macroeconomic policies have not been successful in reducing the degree of uncertainty in order to provide an environment of confidence strong enough to boost long-term physical investment and innovation. We will support in this same Subsection the hypothesis that the main challenge policy-makers face is to balance these supply-side incentives with the demand-side ones. This challenge might be greater if we consider that the institutions to coordinate the supply and demand side incentives of economic policy are still weak in Brazil, after decades of stabilization convention to growth. Lastly, the last section presents our final considerations.

\section{THE ANALYTICAL APPROACH: KEYNESIAN CONVENTION AND NEO-SCHUMPETERIAN NATIONAL INNOVATION SYSTEM}

As anticipated in the Introduction, our point of departure to our analytical approach is the Keynesian concept of convention. Keynes (1936, p. 152) assures that "the essence of $[\ldots]$ convention [...] lies in assuming that the existing state of affairs will continue indefinitely, except in so far as we have specific reasons to expect a change". This concept could be adapted and briefly summarized as the way that the incorporation and support of the set of economic decisions related to different objectives, such as investment, real GDP growth, price stability, tax system, financial system and so on, are carried out by the majority of the political, economic and social institutions.

Keynes (1936, p. 152) implicitly assumes that "since our existing knowledge does not provide a sufficient basis for a calculated mathematical expectation", in practice the term convention guides the state of confidence related to important decisions such as investment and, therefore, the other component associated with aggregate demand. In other words, convention governs, at least partially, the behavior of the real GDP. In Keynes' (1936, p. 152) words, some situations could be maintained, "as long as we can rely on the maintenance of the convention" (italics from the original).

It is important to stress that the effort of using the concept of convention was pioneered in Brazil by Castro (1993), who analysed the crisis of the 1980s in Brazil by showing the duality between the convention to growth versus the convention to price stability. Erber (2004), influenced by the original Castro's (1993) contribution, also showed by means of the concept of convention of development how the boost in innovation in Brazil was damaged by the liberal vision that prevailed throughout the 1990s. The analytical reference of convention can also be connected to the Neo-Schumpeterian National Innovation System (NIS) concept. Although several definitions for the Neo-Schumpeterian concept of the National Innovation System (NIS) can be found in the economic literature, in more recent versions most authors emphasize that not only institutions per se, but mainly the complexity of interactions among them matter for both micro and macroeconom- 
ic performance. Johnson, Edquist and Lundvall (2003, p. 4) observe that these interactions occur in the context of "laws, rules, regulations, norms and cultural habits", among institutions. So do Lundvall et al. (2002, p. 214), who recognize that, despite combining ideas taken from different areas, such as economic policies, economic interdependence, economic change and so on, the integration of these elements is "much shakier than the integration of the elements of a technological innovation like the modern computer".

As Keynes (1936) pointed out a long time ago, money and institutions related to macroeconomic policies matter in the sense that, more than preserving price stability in the short term, they are essential to explain long-term growth in monetary economies. However, the NIS approach is almost silent about the interactions between the conventional macroeconomic policies and other institutions that form the innovation and technological system. ${ }^{2}$

This does not mean that those connections are not recognized by the NIS literature. For instance, in the above quotation from Lundvall et al., those interactions are implicit. Along the same line, Lastres and Cassiolato (2003, p. 6), in a paper discussing "systems of innovation and development from a South American perspective", stress "the importance of taking into account the productive, financial, social, institutional and political spheres, as well as micro, meso and macro dimensions" (boldface ours). In a critique of the narrow view with which the World Bank and the International Monetary Fund (IMF) analyze the role of institutions for development, Johnson, et al. $(2003$, p. 10) argue that the crucial issue is that "the impact on learning and innovation of, for example, labour market institutions, financial institutions, economic policy regimes and a host of norms supporting a learning culture are not analyzed" (boldface ours). However, these connections are hardly found - at least to a satisfactory degree of detail — neither in theoretical nor in empirical studies.

Financial globalization since the 1990s, by drastically increasing capital flows, has significantly increased monetary and exchange rate volatility in peripheral economies, and it has reinforced the interdependence between monetary and exchange rate policies. As recently demonstrated by Razin and Loungani (2005), since trade liberalization and financial globalization have allowed households to grow and diversify consumption possibilities, it follows that reduced weight has been given to output gaps relative to inflation. As Central Banks react to these demands rather than growth, monetary policy has given major priority to price stability. The empirical evidence shows that the more a country is exposed to trade and capital account liberalization, the greater will be the loss of output required for reducing inflation and keeping it at stable rates. For a country like Brazil, which has had a

\footnotetext{
${ }^{2}$ Coriat and Weinstein (2002) express concern over the "conceptual vagueness" of the term "institutions" in the NIS literature. They propose to interface the 'organizational approach', which conditions a firm's choices in a capitalist system, with the 'institution approach', which emphasizes the role of the NIS for determining a country's economic performance. Even so, the macroeconomic element does not appear clearly and with satisfactory detail in their proposed approach.
} 
long history of high inflation rates, monetary policy has since the mid-1990s been the main transmission channel to bring inflation down and preserve price stability. In a context of large capital flows, this required extremely high real interest rates from the Brazilian Central Bank until 2011. As Coutinho (2003) appropriately points out, a "macroeconomic regime contains and conditions the microeconomic decisions that form the standards of financing, corporate governance, international trade, competition and technical change."

In the next sections, we will show that, in the case of Brazil, one of the main reasons why long-term growth has been sluggish is that there is clearly a poor coordination among institutions involved in the implementation of industrial and technological policies (which are related to the Brazilian Innovation System - that is to say, all institutions associated with the generation and diffusion of innovations stricto sensu) and the other economic institutions, especially those which carry out monetary, financial, fiscal and exchange rate policies. In addition, contradictory instruments applied through long-term industrial and technological policies and through short-term conventional macroeconomic policies have been observed many times. We will emphasize that this poor coordination has been worsening since the early 1990s, when the liberal convention began to dominate the debate and the implementation of economic policy in Brazil.

\section{DIFFERENT GROWTH CONVENTIONS IN BRAZIL}

\section{(1) Growth convention in the 1970s and the 1980s: a brief review}

Since the post-World War II until the beginning of the 1980s, the Brazilian economy grew above the average of developed and underdeveloped economies, showing strong vigor under the leadership of the manufacturing sector. This was a result of the "state-led-industrialization" process, according to Eclac's terminology, based on import substitution to promote the catching up of the Brazilian economy. Between 1947 and 1970, the manufacturing sector increased its participation in the National Income from 19.3 per cent to 27.4 per cent, and it reached 31.3 per cent in 1980. The main industrial sectors to explain such performance were the production of capital goods and durable goods.

However, such a deep transformation in the productive structure came together with macroeconomic imbalances. So, an important feature of the import substitution strategy followed by the country was the increased dependency on foreign capital to finance growth, generating recurrent balance of payments problems. In addition, chronic and high inflation had always been presented in the Brazilian economy from the 1980s until 1994. Following the structuralism interpretation, these imbalances were the result of the speed and intensity of the transformations in the productive structure triggered by rapid industrialization in this period. The success of the developmental strategy, under the state-led-industrialization process until the 1980 s, was succeeded by a pro-stability strategy under lib- 
eral structural reforms in the 1990s. This means that the convention to growth until the 1980s, based largely on state intervention through state firms, development banks and external savings, was replaced by the convention to growth based on market forces in the 1990s.

Going back to the 1970s, this period was the most dynamic period in Brazilian economic history. After a brief deceleration of the accumulation process in the mid1960s, the economy started recovering at the end of the decade, in response to some important institutional changes introduced through the PAEG (Plano de Ação Econômica do Governo), by the military government that took charge in 1964. This plan successfully interrupted the inflationary process, introducing, among other things, a strict wage control. Balance of payments restrictions were eased by the increase in international liquidity, a trend that persisted throughout the 1970s. In addition, in 1968 a policy directed to devaluate the Brazilian currency by crowlingpeg mechanisms (minidesvalorizações) had been introduced in order to avoid overvaluation of the domestic currency.

The 1970s was also marked by the two National Development Plans (PNDPlano Nacional de Desenvolvimento $I$ and $I I$ ). These plans reflected a long-term growth strategy drawn up by a government with a development-oriented outlook, and they privileged the durable goods sectors, an attention later extended to all sectors producing capital and intermediate goods as well as infrastructure. Deep changes in the productive structure of the manufacturing industry took place as well. The first oil shock decelerated the growth rate of the GDP and industrial output, but it did not impair investment plans as government policies supported continued import substitution, while international liquidity provided plenty of finance. The second oil shock and the sudden hike in international interest rates in 1979 undermined this growth trajectory, as it caused the external debt crisis and prevented the economy from continuing to grow as it had until then.

The long cycle of the Brazilian industrialization process under the import substitution strategy led by the state, which had its final phase with the II PND Plan, ${ }^{3}$ seems to have reached its maturity around 1983-1984, when large trade surplus were registered, alleviating external restrictions (Castro and Souza, 1985). It is important to stress that this good performance of the Brazilian exports also benefited from export subsidies, import restrictions and devaluations of the Brazilian currency. From that moment on, the Brazilian economy entered into an accelerated process of rising prices and turning off inflation, the major issue of economic policy. The accelerated growth in the 1984-1986 spell was unsustainable due to the spiralling inflation after the failure of the Cruzado Plan, the first in a sequence of heterodox plans based on price freeze. After that turning point, inflation became the main

\footnotetext{
${ }^{3}$ According to Serra (1982, p. 118), "the Second National Development Plan, was undoubtedly the most important and concentrated effort from the State, since the 'Target Plan' (Plano de Metas), to promote structural changes in the economy." It aimed to broaden the industrial sector and increase the participation of the Brazilian economy in international trade.
} 
obstacle to growth, threatening the sustainability of the rates (and levels) of fixed capital investments in the ensuing years, a situation that would only end in 1994 with the Real Plan.

\section{(2) The stability convention to growth in the circa of liberalizing reforms (1990-2002)}

Economic policy under the Collor de Mello (1990-1992), Itamar Franco (1992-1994) and the first mandate of Fernando Henrique Cardoso (1995-1998) administrations had at least one critical economic problem in common: persistent chronic inflation. Because of that, price stabilization became the main concern of economic policy. During this period, the convention to growth could be interpreted as assuming, implicitly, that growth would resume "automatically" once inflation had been controlled. In this sense, we can say that the long fight to curb high inflation paved the way to the implementation of radical liberalizing reforms, following strictly the recommendations of the Washington Consensus, such as trade liberalization (1990-1994), ${ }^{4}$ privatization of state enterprises (from 1990 on) and financial liberalization and openness of the short-term capital account. ${ }^{5}$

Therefore, after a long period of high inflation and low growth, the 1990s were a period of dramatic change for the Brazilian economy. The most important achievement was the end of the high inflation regime after the successful implementation of the Real Plan in 1994. Besides price stability, the 1990s were also marked by the opening of the economy, following a more liberal approach to development, with less State intervention. In order to briefly describe this period, we shall divide it into two sub-periods: before price stabilization (1990-1993), and after price stabilization until the end of the Fernando Henrique Cardoso's administration (1994-2002). Emphasis will be given to economic policy and the liberal structural reforms, and how private firms, mainly in the industrial sector, reacted to changes in the macroeconomic environment.

The first phase was characterized by an environment of high inflation and low growth, and also by the beginning of the trade liberalization process, coupled with a set of institutional reforms relating to the deregulation of the economy. This economic context can be identified by high uncertainty in both the macroeconomic and microeconomic spheres.

In 1990, President Collor's administration launched the new industrial plan, PICE Política Industrial e de Comércio Exterior, which meant a sharp break from

\footnotetext{
${ }^{4}$ At the end of the 1980s, the level of protection of the Brazilian economy was very high. Trade liberalization, among all reforms, can be seen as the most necessary one to boost domestic productivity. However, it happened too fast, compared, for instance, to India. As a result, the average level of tariffs in Brazil was $10.4 \%$ (in 2004), against $32.3 \%$ in India (in 2002), and it was much less than the consolidated level at the World Trade Organization (WTO). See Nassif (2007, p. 14).

${ }^{5}$ For details, see Nassif (2007).
} 
the prevailing pattern of industrial policy in previous decades. This policy pointed out the necessity to increase efficiency in production, and the marketing of goods and services, through the modernization and restructuring of the industry. In particular, it indicated that market forces should play a strategic role to induce technological upgrading of the industrial park and to improve the forms of organization of production and labour management. The PICE abolished most non-tariff barriers inherited from the period of import substitution and set a timeline for reducing import tariffs. The reductions would be phased in between 1990 and $1994 .{ }^{6}$

This policy, implemented in a period of economic recession and high inflation, had the effect of inducing industrial companies to defensive adjustments in productive processes, in order to cut operational costs. Facing greater competition, modernization of the industrial sector occurred primarily through the introduction of management procedures, and not through investments in new plants and equipment (Castro, 2001).

The trade liberalization process came with an agenda of structural reforms, ultimately aimed at creating a stable economic environment with an emphasis on market forces. It was believed that the introduction of structural reforms would "naturally" encourage growth and attract foreign capital. As shown in Erber (2011), trade liberalization would promote a virtuous circle of growth as a result of structural reforms, designed according to the Washington Consensus. According to the author, the reforms proposed were seen as a positive agenda (in opposition to a negative agenda that should be avoided) of economic policy which aimed at price stabilization, the control of the public deficit, the privatization of state enterprises and the creation of regulatory agencies, the elimination of differences between local and foreign companies, the elimination of price controls by the state and the establishment of a regulatory system to prevent economic power abuse, the liberalization of foreign capital inflows, the establishment of a new legislation for intellectual property rights, the liberalization of the labour market and the strengthening of regional integration with the Mercosur.

The effects of the liberal reforms in the productive structure would become clear in the next period, when the rate of productivity growth in the economy started to grow, after a long stagnation period since the mid-1980s. At the beginning of the decade, two events positively marked the macroeconomic scenario: the Brady Plan that brought relief to the Brazilian international commitments and the return on external capital flows due to the increased volume of international liquidity and the opening of the domestic financial system to international capital flows.

In short, the first years of the 1990s registered the beginning of the adjustment of private firms to the opening of the economy via a reduction in the production

\footnotetext{
${ }^{6}$ At the end of the period, the maximum rate would be 40 per cent, the mean tariff around 14 per cent and the modal of 20 per cent and standard deviation of less than 8 per cent. The tariff schedule was maintained only until October 1992, when there was an anticipation of reductions planned for 1993 and 1994, and in 1995, the structure of tariff protection underwent new change again. In September 1994, the Mercosur common external tariff (TEC) came into force. See Kume, Piani and Souza (2003).
} 
costs, in particular in the manufacturing industry. The recessionary environment and high price instability did not resume investment in fixed capital. At the same time, this was a phase when significant changes in the rules, the conventions of economic policy and institutional arrangements began to be introduced, also acting negatively on the level of uncertainty in business decisions, as growth prospects did not improve. On the positive side, there was a resumption of foreign capital inflows.

The next period was marked by the success of the Real Plan in 1994 to stabilize prices. Price stability was anchored in the exchange rate, which was fixed at parity $1 \mathrm{R} \$ / 1 \mathrm{US} \$$. At first, given the high capital inflows that had been occurring, the trend of the exchange rate was to be appreciated. The Mexican crisis in December 1994, however, led to a sharp contraction of capital flows, and in March 1995 the Central Bank allowed free floating of the exchange rate (actually, a dirty floating exchange rate regime) within pre-set limits. This scheme was only extinguished with the speculative attack in January 1999, prompting the Central Bank to set the floating exchange rate regime.

The successful stabilization of prices if, on the one hand, contributed to the transparency in the economic decision making process, on the other, was accompanied by a growing imbalance in the external accounts. The external crisis that ensued in 1997 in Asian countries, and in 1998 in Russia, made evident the country's dependence on short-term capital. The mechanism of the exchange rate anchor to keep prices under control, as it allowed the exchange rate appreciation, caused a systematic increase of the current account deficit, negatively impacting business expectations.

During the consolidation phase of the exchange rate band regime, the Central Bank's strategy was to fight speculative attacks against the Brazilian real through rising interest rates. Thus, the high current account deficits caused by both deficits (in the trade balance and in the income balance), increased the economy's dependence on foreign short-term capital, preventing interest rates from falling. ${ }^{7}$ The main source of macroeconomic uncertainty at this stage was the behaviour of domestic interest rates that kept the country with low growth and inhibited the resumption of productive investments. The expected virtuous growth circle that would have come with the liberal structural reforms, once it exposed the external fragility of the Brazilian current account, actually led the economy to a "trap" of high interest rates and low growth (Delfim Netto,1998). Economic growth was higher in the first two years of this period. However, as the external fragility of the economy appeared as a structural problem rather than a temporary one, growth rates slowed, especially after the Asian crisis in mid-1997.

From the microeconomic point of view, the appreciation of the exchange rate, though, allowed the cheapening of inputs and capital goods for the modernization of production processes, made imports of finished products competitive, and in-

\footnotetext{
${ }^{7}$ For a critique on the dependency of external savings to grow, see Bresser-Pereira and Nakano (2003) and Bresser-Pereira and Gala (2007).
} 
creased competition with domestic production. The reaction of companies, particularly in the industrial sector, was to deepen the adjustment process, seeking a restructuring of production by increasing the standards of economic efficiency (Castro, 2001). In contrast to the previous stage, productivity started to grow in response to modernization in the industrial productive structure, which occurred largely with reduction in industrial employment, since the investment rate did not improve. ${ }^{8}$

The expectation that the economic opening, along with institutional liberal reforms, would lead to a balanced increase in imports and exports did not occur. ${ }^{9}$ From the macroeconomic point of view, the main reason was that the exchange rate was kept overvalued to stabilize inflation. Again from the microeconomic point of view, companies turned more to the domestic market than the foreign one, stimulated by the consumption boom after the Real Plan. Thus, unlike the expectations of the virtuous circle of liberal reforms, changes in the macroeconomic environment reinforced the importance of the domestic market, leading to a contradiction between what occurred at the microeconomic level (modernization of enterprises and increasing productivity) and the needs of the economy as a whole (generation of trade surplus to reduce external dependence on foreign capital). The Fernando Henrique Cardoso industrial policy was largely subordinated to economic stability, e.g., there was the belief that an economy with solid macroeconomic fundamentals would provide the necessary and sufficient condition to leverage economic growth and productivity. This perception started to change under President Luiz Inacio Lula da Silva's administration.

In January 1999, the semi-fixed exchange rate regime was abandoned, following the speculative attack after the Russian crisis. To avoid the explosion of inflation after the overshooting of the exchange rate, interest rates were increased, reaching up to 40 per cent a month. An economic recession followed. This very negative macroeconomic environment contributed to increasing the degree of uncertainty in the economy even more. In addition to the high and volatile domestic interest rates, the economy began to also live with exchange rate instability.

In sum, the 1990-2002 period is one of poor growth of the GDP (2.0 per cent per year on average), a rate well below the historical trend, with stagnant employment. Productivity gains in a recessive context were achieved at the expense of rising unemployment. The opening of the economy and the liberal institutional reforms resulted in a higher degree of external fragility of the domestic economy, without deepening the technological catching up of the Brazilian economy. Thus, the consolidation of the liberal convention to growth did not deliver what it intended to, leading to a revision of the growth strategy for the rest of the decade.

\footnotetext{
${ }^{8}$ The rate of investment to GDP decreased from $20.8 \%$ in 1994 to $19.8 \%$ in 1998 .

${ }^{9}$ Mendonça de Barros and Goldenstein (1997) describe well how the opening of the economy would boost growth and productivity.
} 
(3) The duality between the liberal and neo-developmental conventions to growth: the recovery of industrial policies under Lula da Silva's two mandates (2003-2010)

The two presidential mandates of Luiz Inacio Lula da Silva can be analyzed considering two different approaches to the convention to growth: in the 2003-2006 mandate, a liberal convention prevailed (for different reasons than that of his predecessor); in the 2007-2010 mandate, despite governmental efforts to implement a pro-growth convention, the liberal and pro-stability conventions conflicted with the pro-growth convention in such a way that the liberal convention prevailed.

The liberal convention of his first mandate is linked to the electoral campaign that gave him victory in the presidential election. In fact, during the electoral campaign, in 2002, expectations deteriorated and a severe confidence crisis emerged in the financial sector, which labelled Lula da Silva as a leftist candidate who would break contracts and property rights. The consequence was a massive capital flight and a strong depreciation of the Brazilian real. This forced Lula da Silva to commit himself to keeping all the basic macroeconomic policies of Fernando Henrique Cardoso's second mandate: inflation target, targets for primary fiscal surplus and a floating exchange rate regime, as exposed in a public document known as the "Letter to the Brazilian people".

While the macroeconomic policy followed the liberal convention, Lula da Silva's administration deepened social policies to reduce poverty and to improve educational standards, facilitating the access of the poor to technical high and secondary schools. In order to increase the participation of low income families in the mass consumption market, the Lula da Silva administration implemented the Family Grant Programme (Bolsa Família) - a cash transfer social programme for families with children on the condition their children attend school -, gave special access to credit for retired persons, and implemented a policy of increasing the purchasing power of the minimum wage. As Erber (2011, p. 20) pointed out, these policies could be interpreted, in principle, as the "need of a new convention of development" which could go beyond the prevailing liberal convention of the 1990s.

Notwithstanding these attempts, in the first Lula da Silva mandate, since the macroeconomic policy did not change, the previous Fernando Henrique Cardoso's liberal convention to growth prevailed. ${ }^{10}$ The duality of the Lula da Silva administration following an orthodox macroeconomic policy can also be seen considering that, even under the neo-liberal macroeconomic agenda, there was an attempt to restore an agenda of industrial and technological policy. This was done with the release of the Industrial, Technological and Foreign Trade Policy - PITCE (Politi-

\footnotetext{
${ }^{10}$ In the beginning of Lula da Silva's first mandate, the Ministry of Finance released a document emphasizing that priorities should fall on price stability, on a long-term fiscal adjustment, on the reform of the public pension system and on the modernization of Brazilian institutions (see Ministry of Finance, 2003). In 2004, Palocci Filho, the Minister of Finance, supported a microeconomic agenda with the aim of helping to sustain the process of recovering growth in the Brazilian economy.
} 
ca Industrial, Tecnológica e de Comércio Exterior) in 2003. The importance of the PITCE was that, for the first time since the 1980s, there was an effort to restore sectoral programmes in Brazil. In the case of the PITCE, priority was given to sectors such as capital goods, electronic components, software and pharmaceutical products. Special attention was also given to areas of new technologies, such as biotechnology, nanotechnology and biofuels. ${ }^{11}$ However, due to the lack of coordination with macroeconomic policy, which emphasised price stabilisation and fiscal adjustment, PITCE did not present any significant result.

In his second mandate, Lula da Silva kept the main pillars of the neo-liberal macroeconomic agenda: inflation target and primary fiscal surplus. As discussed in Ocampo and Vos (2005), this sort of policy agenda reduces policy space in developing economies, since their growth cycles are determined by the external environment, and little room is left for contra-cyclical measures. However, the growth concern was made explicit in Lula da Silva's second mandate with the launching of a new plan to stimulate investment: the Policy for Accelerating Growth - PAC (Política de Aceleração do Crescimento).

The PAC proposed to invest a total of $\mathrm{R} \$ 503.9$ billion (around US\$ 251.9 billion) in the 2007-2010 period, having as the driving force infrastructure areas like sanitation, popular housing, transport and energy. Federal funds would come mostly from state enterprises ( $\mathrm{R} \$ 219.2$ billion) and only $\mathrm{R} \$ 67.8$ billion from the Union budget. The private sector was expected to contribute with $\mathrm{R} \$ 216.9$ billion. In fact, the $P A C$ can be understood as a Keynesian fiscal policy designed to boost private "animal spirits". ${ }^{12}$

In 2008, Lula da Silva's government released a more complex and ambitious programme of industrial and technological policy: the Policy for Productive Development (Politica de Desenvolvimento Produtivo - PDP), which was raised with the motto "innovate and invest to sustain growth" in Brazil. Differently from the PITCE, 25 sectors were targeted by the PDP. In fact, while PITCE focused on a few strategic sectors, the PDP targeted sectors for consolidating and expanding leadership (aeronautics; oil, gas and petrochemicals; bio-ethanol; proteins; mining; steel; and pulp and paper, among others), for strengthening competitiveness (automobile; capital goods; textile and apparel; among others), and for building up technological capabilities (health industries; information and communication technologies; nuclear energy; defence; nanotechnology; and biotechnology). The systemic orientation of the PDP is revealed considering that it also made strategic choices such as to expand exports, to strengthen small and medium enterprises, to increase the production integration between Latin America and Africa, to disseminate regional clusters and to contribute to generating clean production. ${ }^{13}$ It is too

\footnotetext{
${ }^{11}$ See MDIC (2003).

${ }^{12}$ In order to put the $P A C$ in action, the target for primary fiscal surplus could be reduced from 4.25 per cent of the GDP to 3.75 per cent of the GDP if necessary.

${ }^{13}$ For details on PDP, see Coutinho et al. (2012).
} 
early to evaluate the performance of such an ambitious industrial programme, not only because of its complexity, but also in virtue of the negative effects of the post-2008 global economic crisis on the Brazilian economy, whose main consequence was to either reduce or paralyze most private investments in Brazil.

The performance of the Brazilian economy in the second mandate of Lula da Silva's government (2003-2010) was better than his first mandate and even better than the two mandates of Fernando Henrique Cardoso's (see Tables 1 and 2, with the main macroeconomic indicators). The main reason, however, for Lula da Silva's best performance was the boom in foreign trade and the improvement in the terms of trade up until 2008. The international financial crisis that reached the Brazilian economy at the end of 2008 interrupted this good moment, deteriorating business expectations and increasing the degree of uncertainty in the economy.

Table 1: Brazil: Selected macroeconomic indicators under

Fernando Henrique Cardoso's (FHC) administration (1995-2002)

\begin{tabular}{|l|c|c|}
\hline \multicolumn{1}{|c|}{$\begin{array}{c}\text { Macroeconomic } \\
\text { indicators }\end{array}$} & $\begin{array}{c}\text { Fernando Henrique Cardoso's 1 } \\
\text { mandate 1995-1998 }\end{array}$ & $\begin{array}{c}\text { FHC's 2 }^{\text {nd }} \\
\text { mandate 1999-2002 }\end{array}$ \\
\hline $\begin{array}{l}\text { Average real GDP growth } \\
\text { (per cent p.y.) }\end{array}$ & 2.5 & 2.2 \\
\hline $\begin{array}{l}\text { Consumer inflation rate - IPCA } \\
\text { (average per cent p.y.) }\end{array}$ & 9.7 & 8.8 \\
\hline $\begin{array}{l}\text { Basic interest rate - Over/Selic } \\
\text { (average per cent p.y.) }\end{array}$ & 33.7 & 19.7 \\
\hline $\begin{array}{l}\text { Real basic interest rate - Over/Selic } \\
\text { (average per cent p.y.) }\end{array}$ & 21.9 & 10.0 \\
\hline $\begin{array}{l}\text { Nominal fiscal deficit/GDP* } \\
\text { (average per cent p.y.) }\end{array}$ & $(-6.8)$ & $(-7.2)$ \\
\hline $\begin{array}{l}\text { Primary fiscal balance/GDP** } \\
\text { (average per cent p.y.) }\end{array}$ & $(-0.2)$ & 3.3 \\
\hline $\begin{array}{l}\text { Current account balance/GDP } \\
\text { (average per cent p.y.) }\end{array}$ & $(-3.2)$ & $(-3.4)$ \\
\hline
\end{tabular}

Notes: ${ }^{*}$ Includes interest expenditures; ${ }^{*}$ Includes exchange rate depreciation on domestic securities.

Source: Ipeadata (http://www.ipea.gov.br).

Table 2: Brazil: Selected macroeconomic indicators under Lula da Silva's administration (2003-2010)

\begin{tabular}{|l|c|c|}
\hline \multicolumn{1}{|c|}{$\begin{array}{c}\text { Macroeconomic } \\
\text { indicators }\end{array}$} & $\begin{array}{c}\text { Lula da Silva's 1 } \\
\text { mandate 2003-2006 }\end{array}$ & $\begin{array}{c}\text { Lula da Silva's } \\
2^{\text {nd }} \text { mandate 2007-2010 }\end{array}$ \\
\hline $\begin{array}{l}\text { Average real GDP growth (per cent } \\
\text { p.y.) }\end{array}$ & 3.5 & 4.6 \\
\hline $\begin{array}{l}\text { Consumer inflation rate - IPCA } \\
\text { (average per cent p.y.) }\end{array}$ & 6.4 & 5.1 \\
\hline $\begin{array}{l}\text { Basic interest rate - Over/Selic } \\
\text { (average per cent p.y.) }\end{array}$ & 16.3 & 11.4 \\
\hline
\end{tabular}




continued
\begin{tabular}{|l|c|c|}
\hline $\begin{array}{l}\text { Real basic interest rate - Over/Selic } \\
\text { (average per cent p.y.) }\end{array}$ & 9.3 & 6.0 \\
\hline $\begin{array}{l}\text { Nominal fiscal deficit/GDP* } \\
\text { (average per cent p.y.) }\end{array}$ & $(-3.8)$ & $(-2.7)$ \\
\hline $\begin{array}{l}\text { Primary fiscal balance/GDP** } \\
\text { (average per cent p.y.) }\end{array}$ & 3.5 & 2.9 \\
\hline $\begin{array}{l}\text { Current account balance/GDP } \\
\text { (average per cent p.y.) }\end{array}$ & 1.3 & $(-1.4)$ \\
\hline
\end{tabular}

Notes: ${ }^{*}$ Includes interest expenditures (not available for 2010); ** Not available for 2010.

Sources: Ipeadata (http://www.ipea.gov.br); Brazil's Central Bank (http://www.bcb.gov.br).

So, although the Lula da Silva administration had tried to restore policy instruments through industrial and technological policies to fulfil a pro-growth agenda, the attachment to the liberal short-term macroeconomic policy prevailed. Because of that we can say that the Brazilian economy did not overcome the so-called "trilemma" of economic policy, which states that it is not possible to keep monetary autonomy, free capital mobility and low volatility in the exchange rate at the same time. According to Aizenman et al. (2010), Asian economies (except for China), for instance, even without giving up a floating exchange rate regime and freedom of capital movements, have been very successful in by-passing the "trilemma" through an aggressive policy of accumulation of international reserves. In the case of Brazil, from 2006 on, the country had begun to accumulate a massive stock of international reserves, but the degree of interventions in exchange markets had been far from the same aggressive interventions of some Asian countries.

Another critical difference of the Brazilian economy compared with other emerging economies is the high interest rates differential related to the rest of the world. Mostly because of that the Brazilian currency has shown a persistent trend of overvaluation in real terms since 2004. This trend was only interrupted temporarily in 2008, due to the contagion of the global crisis. An estimate of the real appreciation of the real can be found in Nassif et al. (2011). According to the authors, in April 2011, the Brazilian real was 80 per cent overvalued relative to the long-term "optimal" real exchange rate, that is to say, the level of the real exchange rate that would be enough to induce the re-allocation of resources from sectors of low to high productivity.

So, considering that the real exchange rate is a strategic price to induce the development of high technological sectors, the persistent trend of overvaluation of the Brazilian currency might have reduced the profit expectations of firms in the tradable sectors, the ones that compete simultaneously in both domestic and foreign markets, and also might have increased the opportunity cost for investment and innovation. As a result, this could be partially responsible for the low ratio of gross investment to GDP in Brazil, especially if one compares the same indicator with countries like China and India. ${ }^{14}$ Consequently, despite the governmental efforts to

\footnotetext{
${ }^{14}$ In Lula da Silva's first mandate (2003-2006), the ratio gross capital formation to GDP was only $16.0 \%$ (on average), while in his second mandate (2007-2010) this same indicator had a slight increase to
} 
implement industrial and technological policies, the macroeconomic context of the political economy did not favour microeconomic decisions to boost investment.

Another example of the duality concerning the conventions to growth - the liberal and the neo-developmental - characteristics of Lula da Silva's second mandate can be given by the immediate reactions of Brazilian policy-makers to the 2008 global crisis. On the one hand, the Brazilian authorities were quick to provide liquidity to the financial system to offset the tight private credit squeeze. This was done by granting additional resources to government-owned export-import banks (EXIM banks) and State development banks so that they would be able to finance trade, companies and households. Yet in September 2008, while the Brazilian Development Bank (BNDES) - traditionally oriented to financing investment in industry and infrastructure - was allowed to provide credit lines to finance working capital, the Banco do Brasil and Caixa Econômica Federal acted as "quasi lenders of last resort" by purchasing portfolios from small and medium-sized private banks that were facing serious liquidity problems. Another important decision was taken in January 2009, when the Brazilian Treasury announced an additional credit facility of R $\$ 100$ billion (3.3 per cent of GDP) to the BNDES, which aimed at augmenting its credit for working capital and for small and medium-sized enterprises as well as for boosting private investment in sectors with high income multiplier effects, especially infrastructure. However, it took some time until the BNDES actually created the special Programme for Sustaining Investment (PSI), in July 2009. This additional fund helped to restore investment demand in Brazil, but only from mid-2009 onwards.

Contrarily, on the other hand, monetary and fiscal authorities were slow to react in face of the deterioration of the external scenario. This suggests that the main political and economic leaders in Brazil were still influenced by the decoupling hypothesis. ${ }^{15}$ For instance, in October 2008, President Lula da Silva declared that "rather than an economic tsunami like in the U.S., the financial crisis in Brazil will be a little wave." ${ }^{16}$ In this same optimistic vein, in November 2008 the chairman of Brazil's Central Bank, Henrique Meirelles, still believed a real GDP growth of 3 per cent in 2009 would be possible: "Even in this moment of a serious world crisis, the greatest since 1929, Brazil will have a growth greater than the yearly average growth shown in the period 1980-2003." ${ }^{17}$ This belief was expressed despite an

$18.9 \%$ (on average). Data from Ipeadata (http://www.ipea.gov.br). In 2009, the gross capital formation to GDP had already reached $36 \%$ in India and $48 \%$ in China. For details, see Agarwal and Whalley (2013, p. 8).

${ }^{15}$ According to the decoupling hypothesis, the increasing importance of Asian countries (particularly China) in world GDP would prevent the recession in the United States from spilling over to the global economy. In an important paper, Akin and Kose $(2007$, p. 6 ) had already clarified the decoupling debate, showing empirical evidence that "while the impact of the North (in terms of economic growth) on the Emerging South groups has declined over time, it has not changed much on the latter one."

${ }^{16}$ O Globo, 4 October 2008.

${ }^{17}$ Agência Brasil, 28 November 2008. 
environment of rapid deceleration of monthly manufacturing production. Indeed, the real GDP fell 3.6 per cent in the last quarter of 2008 compared to the immediately preceding quarter. Only in March 2009 did economic authorities start to react with more expansionary monetary and fiscal policies.

While Brazil's Central Bank reduced the basic interest rate (Selic) to 11.25 per cent (a cut of 150 basis points), policy-makers recognized the urgency of increasing the resources allocated to public investment programmes, of creating mechanisms to boost private investment and of reducing the primary fiscal surplus target. ${ }^{18}$ Two measures were taken in this direction: first, a new housing programme (Minha Casa, Minha Vida Program) was adopted with the aim of building one million houses by 2010, financed by additional public subsidies amounting to $\mathrm{R} \$ 34$ billion (approximately 1.2 per cent of the GDP); and second, by July 2009, the BNDES began to implement the Programme for Sustaining Investment (PSI), which granted loans with favourable interest rates for the production and purchase of capital goods and for innovation projects. This latter measure played an important role in restoring investment demand in Brazil from mid-2009 onwards. Through PSI, the interest rate on Finame loans (a BNDES programme for promoting the purchase of machinery and equipment) was reduced by 0.6 percentage points, reaching 4.5 per cent per annum. At the time PSI was implemented (in July 2009), daily disbursements from Finame reached their lowest level (R \$ 60 million, or US\$33 million). In December 2009, they had already recovered and reached $\mathrm{R} \$ 182$ million (US\$ 101 million), an amount superior to that posted in September 2008.

Summing up, despite the duality in the growth convention, that is to say, on the one hand, under the liberal orientation focusing on price stability and, on the other hand, the attempt to restore industrial and technological instruments to overcome more structural bottlenecks to accelerate the rate of real GDP growth, the liberal convention dominated the macroeconomic domestic scenario. This brought as a main consequence in both of Lula da Silva's mandates a significant real exchange rate overvaluation, which was partially responsible for the fragility of the industrial structure, the reprimarisation of the export basket and early de-industrialization in Brazil. ${ }^{19}$ So, we conclude here that the contradictions in implementing a developmental agenda without getting rid of the liberal agenda, mainly after the financial crisis, resulted in a deep crisis in the industrial sector, which became clear in 2011 and 2012 when GDP growth was disappointing, with negative consequences for the growth productivity in the economy.

\footnotetext{
${ }^{18}$ In April 2009, the Brazilian government submitted an amendment to the Law of Budget Guidelines to Congress, proposing the temporary reduction in the primary fiscal surplus target of $3.8 \%$ to $2.5 \%$ of GDP with the aim of releasing further funds for increasing public investment and other government expenditures.

${ }^{19}$ For details, see Nassif et al. (2013).
} 
(4) Challenges to reinforce the neo-developmental convention to growth in a world of "depression economics": the Dilma Rousseff government (2011-2014)

The high popularity of former president Lula da Silva helped to elect Dilma Rousseff for the 2011-2014 period. In our view, as she took power, one of her main challenges was to create opportunities (that is to say, to increase the policy space) to reduce the still very high nominal (and real) interest rates in Brazil (see Table 2), and that meant replacing the convention of high interest rates that had prevailed under the liberal convention to growth, for a new one of low nominal and real interest rates, more adequate to the scenario of world depression.

In September 2011, the newly appointed chairman of the Central Bank, Alexandre Tombini, even in a domestic scenario of increasing inflation rates and increasing inflationary expectations, announced a long cycle of decrease in the basic interest rates in Brazil. From September 2011 to April 2013 the nominal basic interest rates were reduced from 12.0 per cent to 7.25 per cent, corresponding to a real drop from around 5.2 per cent to 1.3 per cent in the same period. ${ }^{20,21}$ The decrease in the basic interest rate has been justified by the negative expectations about the recovery of the world economy.

In fact, throughout the second semester of 2011 and early 2012, the world economic scenario deteriorated with the deepening of the crisis in the Eurozone without any short-term solution in sight; the U.S. economy has been recovering very slowly; and the Chinese economy sharply decelerated in comparison with the performance that prevailed before the 2008 world economic crisis. All these adverse events have negatively impacted the expectations in Brazil and have been partially responsible for the low real GDP growth in the two first years of Dilma Rousseff's government (2011 and 2012).22

A question to be raised is why the negative expectations about the world economy did not influence other emerging economies (e.g., some Asian countries) in the same way they did in Brazil. A possible answer is that the Brazilian economy has suffered an intense process of early de-industrialization in the past decades, deepening its dependence on exports of primary products and industrial commodities based on natural resources. ${ }^{23}$ With a fragile and uncompetitive manufacturing sector, the low rates of growth have implied low industrial productivity and, therefore, a vicious cycle that reproduces low rates of growth of the real GDP (the Verdoorn Law).

The Brazilian government has tried to react counter cyclically against the low rates of growth in Brazil. From 2012 to the present, several neo-developmental

\footnotetext{
${ }^{20}$ Ipeadata (http://www.ipea.gov.br).

${ }^{21}$ To give an idea of the severe counter-reactions against the new convention of monetary policy in Brazil, A. Tombini, the new president of the Central Bank of Brazil, had to declare that the Central Bank was "not giving up the inflation target regime". See Valor Econômico, January 23, 2013.

${ }^{22}$ In 2011 and 2012, the real GDP increased only $2.7 \%$ and $0.9 \%$, respectively.

${ }^{23}$ For details on both phenomena, see Nassif et al. (2013).
} 
measures have been introduced with the goal to produce stimuli from the supply side of the economy. Table 3 summarizes the main actions.

Table 3: The main stimuli to growth of Dilma Rousseff's government

\begin{tabular}{|c|c|}
\hline Area & Main stimuli \\
\hline The Brazilian Development Bank (BNDES) & $\begin{array}{l}\text { - Increasing BNDES's funding through lending } \\
\text { from the National Treasury to the BNDES, to- } \\
\text { talling the amount of R\$285 billion (US\$ } 142.9 \\
\text { billion) from January } 2009 \text { to September } 2012 \\
\text { - Disbursement to the Programme for Sustain- } \\
\text { ing Investment (PSI) - a total of R } \$ 85.016 \\
\text { billion }\end{array}$ \\
\hline Plano Brasil Maior — April 2013 & $\begin{array}{l}\text { - Several strategic actions (basically tax } \\
\text { exemptions or reductions and incentives } \\
\text { to innovation) in different sectors, such as } \\
\text { capital goods, automobiles, technology of } \\
\text { information and communication, oil and gas, } \\
\text { chemicals and others }\end{array}$ \\
\hline Infrastructure & $\begin{array}{l}\text { - Roads and railroads: in roads, public } \\
\text { concessions for private investments; } \\
\text { in railroads, private-public partnerships }\end{array}$ \\
\hline Investments (PAC Equipamentos) & $\begin{array}{l}\text { - Additional public purchasing of machines and } \\
\text { equipment (a total of } R \$ 6.6 \text { billion and } \\
\mathrm{R} \$ 8.4 \text { billion until 2017). Preference for } \\
\text { national industry even if prices are up to } \\
25 \text { per cent above imported equipment }\end{array}$ \\
\hline Short-term interest rates & $\begin{array}{l}\text { - Reduction of spreads of public banks such as } \\
\text { Banco do Brasil and Caixa Econômica Federal } \\
\text { in order to force private banks to do the same } \\
\text { through major competition }\end{array}$ \\
\hline Capital controls & $\begin{array}{l}\text { - Tax on financial operations of short-term } \\
\text { capital inflows in order to avoid excessive ap- } \\
\text { preciation of the Brazilian currency. In March } \\
2012 \text {, all external borrowings with maturities } \\
\text { less than } 5 \text { years began to pay a tax of } 6 \text { per } \\
\text { cent of IOF (modified ahead for maturities } \\
\text { less than } 2 \text { years) }\end{array}$ \\
\hline
\end{tabular}

Sources: Ministry of Development, Industry and Commerce (http://www.mdic.gov.br); O Estado de São Paulo, August 30, 2012; Valor Econômico, November 30, 2012.

Since most of the measures consist of tax exemptions or reductions as well as increasing the funding of the BNDES for the Programme for Sustaining Growth, the issue is whether they will be able to reactivate the "animal spirits", given the 
above mentioned deterioration of expectations in Brazil. In other words, the question is whether supply-side measures are enough to boost effective demand, especially private investments in Brazil.

Our proposal is that these supply stimuli should be balanced with demandpush stimuli. Since the state of expectations in the future prospects of the economy is still very uncertain, the best policy instrument should come from the fiscal policy, especially through public investments. Given the decrease in the real interest rate, fiscal accounts in Brazil have improved significantly compared with some years ago, and so we suggest a reduction in the fiscal surplus targets (or even the use of a primary fiscal deficit if necessary for a short period of time) for the necessary period of time to restore the state of confidence on expectations to resume growth on a sustainable basis. That is to say, to restore the "animal spirits" to boost investment. As soon as the Brazilian economy shows signs of sustaining growth, the government will return to the practice of primary fiscal surplus. In other words, the redemption of industrial policies well articulated with short-term macroeconomic pro-growth policies is of utmost importance for Brazil to recuperate the capacity to sustain higher rates of economic growth in the immediate future.

\section{CONCLUDING REMARKS}

We discussed in this paper what we called conventions to growth - liberal and neo-developmental - in the last decades in Brazil. Our main contribution is to view economic policy as a combination of short-term macroeconomic policies and industrial and technological policies. Our assumption is that when short-term macroeconomic policies are well coordinated with long-term industrial and technological policies, a growth convention can be identified, implying higher and more sustainable rates of growth. In other words, from the opposite perspective, when short-term stabilizing policies dominate the macroeconomic context and industrial and technological policies are neglected, a liberal convention prevails, implying lower and more volatile growth rates. This kind of approach is in line with Ocampo and Vos (2005), when they analyze the space of policy in emerging economies under the liberal agenda of economic policy. We do not disregard the influence of the external environment on the choices of economic policy, but our emphasis is on the room for manoeuvre that the conduction of economic policies leaves for the domestic economy to pursue a long-term strategy to grow.

A well coordinated economic policy means the use of short and long-term instruments to enable the promotion of structural changes in the direction of boosting sustainable growth. The success of such a combination of policies should be reflected in an increase in the degree of confidence on positive expectations among economic agents. So, this favourable state of confidence would be the necessary condition to induce long-term commitment of financial resources to support long- 
term investment in physical capital. Therefore, in our view, the Brazilian economy has shown a poor economic performance since the 1980s because the conventions to growth have been inadequate for supporting positive states of confidence on long-term growth.

In our analysis we identified that the liberal convention to growth has prevailed most of the time, although since Lula da Silva's mandates it has presented contradictory features. The contradictions are revealed when we take into account, among other things, that attempts to implement industrial and technological policies were made but they were not successful because the conduction of the shortterm macroeconomic policy contributed to a trend of overvaluation of the real exchange rate. As the real exchange rate is a strategic price to induce the development of high technological sectors, the long period of misalignment resulted in early de-industrialization, reprimarization of the export basket and increased fragility of the industrial structure.

The fragility of the manufacturing sector is today one of the most important obstacles to resume growth and labour productivity. Recent economic policy measures, combining some flexibility in the short-term macroeconomic instruments and supply side stimuli to growth have not yet shown good results. In our view, the resumption of investment, a necessary step to improve economic performance, will come when confidence in the future performance of the economy becomes strong enough to induce private decisions with long-term horizons. The challenge of the neo-developmental convention to growth is to build this state of confidence, that is to say, to develop tools and mechanisms for coordination among economic actors around a common development strategy.

\section{REFERENCES}

AGARWAL, M., WHALLEY, J. (2013). "China and India: reforms and the response: how differently have the economies behaved”. Working Paper 19006. NBER Working Paper Series. Cambridge, MA: National Bureau of Economic Research.

AKIN, Ç., KOSE, M. A. (2007). “Changing nature of north-south linkages: Stylized facts and explanations”. IMF Working Paper 280 (WP/07/280). Washington, DC, International Monetary Fund, December.

BRESSER-PEREIRA, L. C., GALA, P. (2007). "Por que a poupança externa não promove crescimento". Revista de Economia Política (The Brazilian Journal of Political Economy), Vol. 27, no 1 (105): 3-19, January-March.

BRESSER-PEREIRA, L. C., NAKANO, Y. (2003). “Crescimento econômico com poupança externa?”. Revista de Economia Política (The Brazilian Journal of Political Economy), Vol. 23, no 2 (90), April-June.

CASTRO, A. B. (2001). “A reestruturação da indústria brasileira nos anos 90: uma interpretação”, Revista de Economia Política (The Brazilian Journal of Political Economy), vol. 21, ํㅡㄴ.

CASTRO, A. B. (1985). “Ajustamento versus transformação: a economia brasileira de 1974 a 1984” In: A. B. Castro e F. E. P. de Souza. A Economia Brasileira em Marcha Forçada. Rio de Janeiro: Paz e Terra.

CASTRO, A. B. (1993). "Renegade development: rise and demise of state-led development in Brazil”. 
In: W. Smith, C. Acuña, and E. Gamarra (eds.). Democracy, Markets and Structural Reform in Latin America. Transaction Publishers.

CORIAT, B., WEINSTEIN, O. (2002). "Organizations, firms and institutions in the generation of innovation”. Research Policy, 31:273-290.

COUTINHO, L. (2003). "Macroeconomic regimes and business strategies: an alternative industrial policy for Brazil in the wake of the $21^{\text {st }}$ century". In: Cassiolato, J. E., Lastres, H. M. M. and Maciel, M L., eds. Systems of Innovation and Development. Elgar, Cheltenham.

COUTINHO, L., FERRAZ, J. C., NASSIF, A., OLIVA, R. (2012). "Industrial Policy and Transformation". In: Santiso, J. and Dayton-Johnson, J. (eds). The Oxford Handbook of Latin American Political Economy. Oxford: Oxford University Press.

DELFIM NETTO, A. (1998). "O Plano Real e a armadilha do crescimento”. in: Mercadante, A. (org.). O Brasil pós-Real, a política econômica em debate. Instituto de Economia da Unicamp.

ERBER, F. (2004). "Innovation and development convention in Brazil”. Revista Brasileira de Inovação, $3(1): 35-54$, january-june.

ERBER, F. (2011). "Convenções de desenvolvimento no Brasil contemporâneo: um ensaio de economia política”. Textos para Discussão Cepal-Ipea LC/BRS/R:230. Comissão Econômica para a América Latina e o Caribe/Instituto de Pesquisa Econômica e Aplicada. mimeo.

JOHNSON, B., EDQUIST, C., LUNDVALL, B. (2003). "Economic development and the National System of Innovation approach”. Unpublished paper presented at Globelics Brazil, 2003.

Keynes, J. M. (1936). The General Theory of Employment, Interest and Money. Cambridge (UK): Cambridge University Press.

KUME H. PIANI, G., SOUZA, C. (2003). “A política brasileira de importação no período 1987-98: descrição e avaliação”. In: Corseuil, C. H. and Kume, H. (eds.). A Abertura Comercial Brasileira nos Anos 1990: Impactos sobre Emprego e Salário. IPEA, Rio de Janeiro.

LASTRES, H. M. M., CASSIOLATO, J. E. (2003). "Systems of innovation and development from a South American perspective: a contribution to Globelics”. Unpublished paper presented at the First Globelics Workshop on Innovation Systems. Aalborg University, Aalborg, Denmark, 4-6 November.

LUNDVALL, B., JOHNSON B., ANDERSEN, E. S., DALUM, B. (2002). "National systems of production, innovation and competence building”. Research Policy, 31:213-231.

MDIC (2003). Diretrizes de Política Industrial, Tecnológica e de Comércio Exterior (http://www.desenvolvimento.gov.br).

MENDONÇA DE BARROS, J. R., GOLDENSTEIN, L. (1997). “Avaliação do processo de reestruturação industrial brasileiro", Revista de Economia Politica (The Brazilian Journal of Political Economy), v. 17, oㅡ 2 .

MINISTRY OF FINANCE (2003). Política econômica e reformas estruturais. Brasília: Ministry of Finance, Brazil (available at http://www.fazenda.gov.br).

NASSIF, A. (2007). "National innovation system and macroeconomic policies: Brazil and India in comparative perspective". UNCTAD Discusión Paper nr. 184. Geneva: United Nations Conference on Trade and Development, May (available at http://www.unctad.org).

NASSIF, A., FEIJÓ, C., ARAUJO, E. (2011). “The long-term “optimal” exchange rate and the currency overvaluation trend in open emerging economies: the case of Brazil”. UNCTAD Discussion paper $n$ r. 206. Geneva: United Nations Conference on Trade and Development, December.

NASSIF, A., FEIJÓ, C., ARAUJO, E. (2013). "Structural change and economic development: is Brazil catching up or falling behind?”. UNCTAD Discussion Paper, forthcoming.

OCAMPO, J. A., VOS, R. (2005). "Policy space and the changing paradigm in conducting macroeconomic policies in developing countries", BIS papers, no 36 .

RAZIN A., LOUNGANI, P. (2005). "Globalization and inflation-output tradeoffs". NBER Working Paper Series, No. 11.641. NBER, Cambridge, MA.

SERRA, J. (1982). "Ciclos e mudanças estruturais na economia brasileira do após-guerra”. Revista de Economia Politica (The Brazilian Journal of Political Economy), vol. 2, ํㅡ 6. 